Article

\title{
Participatory Food Cities: Scholar Activism and the Co-Production of Food Knowledge
}

\author{
Rebecca Sandover (1) \\ Geography, University of Exeter, Exeter EX4 4RJ, UK; r.sandover@exeter.ac.uk
}

Received: 31 December 2019; Accepted: 2 April 2020; Published: 27 April 2020

\begin{abstract}
UK food policy assemblages link a broad range of actors in place-based contexts, working to address increasingly distanciated food supply chains, issues of food justice and more. Academic interest in social movements, such as Sustainable Food Cities, has in recent years taken a participatory turn, with academics seeking to foreground the voices of community-based actors and to work alongside them as part of the movement. Bringing together literatures on multiscalar food governance and participatory methods, this paper investigates the intersection of food policy networks via a place-based case study focused on the co-convening of a community acting to co-produce knowledge of household food insecurity in a UK city. By taking a scholar activist approach, this paper sets out how a place-based cross-sectoral food community mobilised collective knowledge and brought together a community of practice to tackle urgent issues of food justice. Drawing from Borras 2016, it will explore how scholar activism requires the blurring of boundaries between thinking and doing in order to both act with, and reflect on, the food movement. The issues of actively driving forward a food network, along with the tensions and challenges that arise, are investigated, whilst also foregrounding the role academics have in linking food policy and praxis via place-based food communities.
\end{abstract}

Keywords: sustainable food cities; scholar activism; multiscale food networks; knowledge co-production; participatory and engaged research

\section{Introduction}

Community self-organisation around food issues can take place at many levels, from place-based, grassroots action to more formalised and geographically spread approaches. With the present food policy vacuum in England [See Appendix B-I], place-based food communities are collaborating to address food-related issues and work towards change in food policies and programmes [1]. Recent scholarship has explored the emergence of food networks and food policy assemblages to highlight the rising importance of local and translocal action for policy change [2-4]. Bringing together literature on multiscalar food governance and participatory methods, this paper investigates the intersection of food policy networks via a place-based case study. The central focus of the case study is the co-convening of a cross-sectoral community acting to co-produce knowledge of household food insecurity in a UK city. By taking a scholar activist approach, the case study sets out how a place-based cross-sectoral food community mobilised collective knowledge and brought together a community of practice to tackle urgent issues of food justice. Scholar activism, I argue, enables insights into the processes and practices underpinning a food community's evidence gathering and community mobilisation project. An embedded participatory methodology requires a flexible approach to knowledge co-production that enables the breaking down of barriers between academic and popular knowledge [5-8]. Drawing from Borras 2016, this methodology requires the blurring of boundaries between thinking and doing in order to both act with, and reflect on, the food movement [9].

UK place-based community organisations have been self-organising and connecting with different national organisations to form food policy assemblages $[4,10]$. Food policy organisations focus on 
central food issues such as sustainable local food supply chains, access to sustainable local food, household food insecurity and more. Many food-focused activist and campaigning networks such as The Sustainable Food Cities Network (SFCN) [see Appendix B-II], The Landworkers' Alliance, Food Power [see Appendix B-III], La Via Campesina and others intersect at a place-based scale where locally acting self-organising communities take forward programmes of work to enact local food change, whilst also linked to the campaigns of national and translocal networks and frameworks [3,4,11,12]. National UK networks, like SFCN and Food Power, assist place-based organisations' action for food change by offering support, limited funding and sharing tools such as evidence-based reports. Linking place-based, national and translocal scales, food policy assemblages are able to harness community-based knowledge and work to effect policy change within a nested scale by linking actors across these scales $[3,4,11,12]$. An exploration of the terms used here in relation to place-based, national and translocal food policy organisations is set out in Section 2.

The Sustainable Food Cities Network (SFCN), which predominately operates in the UK, encourages place-based civil society organisations to come together and promote a more inclusive and localised food network via creative place-based initiatives. These food partnerships act as increasingly important mechanisms to link food actors, local organisations and policy-makers. The aims of the SFCN include "Tackling food poverty, diet-related ill health and access to affordable healthy food" [13]. Through this, Sustainable Food Cities aim to take an inclusive approach to finding solutions to food issues that acknowledge the breadth of contemporary UK food issues and accusations of exclusion levelled at alternative food networks, such as organic and local food production $[4,14,15]$. Through these actions of network formation and co-producing knowledge, Sustainable Food Cities can influence and/or implement locally adapted programmes and policies that enact food change. Examples include the work of Bristol Food Policy Council's "Bristol Good Food Charter", that seeks to implement actions that support local food enterprises and increase cooking and growing skills in Bristol and more $[2,16]$. Brighton and Hove Food Partnership support a range of food initiatives, including the Community Kitchen, that runs affordable and inclusive cooking classes and provides support for local veg box schemes and farmers' markets [17].

Academic interest in social movements, such as Sustainable Food Cities, includes academics using participatory and co-production methods whereby they seek to foreground the voices of partners and to work alongside them as collaborators within the movement $[2,3,18]$. Co-production is a process that acknowledges the situated contexts within which knowledge is generated and the impacts of these situations on the actors generating knowledge. In particular, a co-production approach recognises place-specific governance, the economic, environmental and social atmospheres that shape the issues affecting communities, the ability for communities to self-organise, the work to influence decision-makers, and more [19-21]. Co-production methodologies are being increasingly adopted by academics taking participatory and collaborative approaches to address critical issues with partners, often with the objective of achieving policy change. The Climate and Development Knowledge Network's 2018 blog explores definitions of this methodology and the core aspects that underpin it. In particular, they highlight how co-productive methods bring together a diverse array of knowledges and experiences in order to produce new knowledge; that project partners hold equal stakes in determining the parameters of the project; and that project partners collaborate to achieve specific end goals [22]. Co-productive methods are of particular value when considering the multilayered complexity of engagements within place-based organisations and food policy assemblages and the roles participatory academics can play within them. Academics are able to advise partners when conducting evidence-gathering processes, analyse data, share relevant literature, co-convene a network and more, a role which is referred to by Moragues-Faus and Morgan [2] (p. 1559) as creating a "community of practice" alongside partners. A "community of practice" is understood as bringing together "groups of people who share a concern, a set of problems, or a passion about a topic, and who deepen their knowledge and expertise in this area by interacting on an ongoing basis" [23]. The term was developed in the 1990s by Lave and Wenger with the objective of promoting social learning through 
collaborating over an extended period of time to develop innovative approaches or solutions to address specific issues $[23,24]$. Through these methods, participatory academics working with place-based food organisations enable the co-production of knowledge such as policy and sector focused reports disseminated within local and wider networks [25,26].

The operating of intersected food policy assemblages impacts the recent projects of Food Exeter, which was established as a sustainable food city in 2014 (previously known as Exeter Food Network). In 2018 Food Exeter also became a "Food Poverty Alliance", after securing funding from Food Power, and began linking up organisations through a cross-city approach to address household food insecurity by establishing their Fair Access to Food Working Group. Initially the working group focused on gathering evidence on food insecurity in the city, as the lack of evidence on this issue and its widespread impacts on people and communities has been widely recognised $[27,28]$. Place-based food organisations are multi sector partnerships that lend themselves to the involvement of participants with a broad range of skills and backgrounds and the reciprocal involvement of academics. My involvement with Food Exeter began in 2016 and I have been closely involved with their core areas of action, specifically the 2017 Food Strategy for Exeter [25] and the 2018 Exeter Food Poverty Summit [26]. This paper explores how a scholar-activist methodology prioritises the co-production of knowledge and acknowledges the potential for reciprocal knowledge-exchange in academic-partner collaborations. Scholar-activists working with the food movement, it is argued here, are able to traverse the nested scales within food policy assemblages, strengthening knowledge co-production and dissemination. By taking this approach, academics have the potential to act as a bridge between policy and praxis at a place-based scale.

Section 2 provides a theoretical context that explores what is scholar activism and how it fits within the spectrum of other engaged research methodologies within Participatory Action Research. Section 3 uses a case study to investigate scholar activism via recent research collaborations with Food Exeter, specifically moments of deep engagement to produce background research for the Exeter Food Poverty Summit in 2018 [see Appendix B-IV]. Throughout, the paper explores the value and challenges of engaging as a scholar-activist with a self-organising place-based food organisation and the processes within these collaborations that enable partners to co-produce knowledge, act for food change and co-convene a community of practice.

\section{Scholar Activism: Literatures of Activism within the Food Movement}

Activism can take many forms, and recent literature has acknowledged the breadth and creativity of methods, that include Everyday Activism, Quiet Activism, Quiet Sustainability and Quiet Politics [29-33]. The commonly perceived view of activism is associated with activists putting themselves at risk and taking iconic actions in order to achieve attention for their cause. The 2018-2019 UK Extinction Rebellion actions and International Rebellion are recent examples of risky activism, where many rebels faced arrest as they called for urgent action to address the climate emergency [34]. In the food movement, action for food change takes many forms, from street protests to the "quiet sustainability" of community gardening, to advocacy and acting for food policy change [30,33]. Kneafsey, Owen et al. [30] (p. 622) explore the quiet radicalism of food growing mentorship programmes:

“... we interpret them as examples of 'capacity building' for food justice, through 'quiet' steps rather than 'radical transformation.'".

In the case study explored here, scholar activism takes a "quieter" approach, and this paper acknowledges the privileged, less risky position of an academic taking an activist position with a self-organising community group largely comprised of actors from professional organisations. Self-organising food communities vary in composition, structure and governance-for example, grassroots activists were central to the formation of Good Food Oxford, whereas Food Exeter was begun by professionals from Exeter Food Bank and The Exeter Diocese in 2014. Food Exeter, responding to a lack of effective UK-wide and Exeter city council food policies, and acting independently of local 
authorities, are strategically advocating for food policy and programme change as a self-organising body. Of central interest here is the transferability of academic skills that enables a scholar-activist to act with community members, take a role in knowledge co-production and co-convene a community of practice. In particular, by both acting with, and reflecting upon, a place-based food organisation, scholar-activists are able to traverse the nested scales of the UK food movement and gain insights from activities and policies implemented elsewhere. However, there are tensions and challenges in taking a scholar-activist role within a place-based food organisation that highlight issues of researcher positionality, which will be explored further in Section 3.

Based in the tradition of Participatory Action Research (PAR), scholar activism attempts to extend conventional understandings of how knowledge can be formed. It is the collaborative, non-hierarchical methodology that makes this an important tool for academics working with partners to address current issues:

"PAR ... involves researchers and participants working together to examine a problematic situation or action to change it for the better." [32] (p. 1)

By participating and acting within social movements, PAR researchers and scholar-activists seek to redefine whose voices are heard and whose knowledge matters when researching social movements $[5,6,35]$. PAR and scholar-activist approaches seek to challenge knowledge and power hierarchies that are embedded in academic-led research. Borras [9] defines scholar activism as:

“... rigorous academic work that aims to change the world, or committed activist work that is informed by rigorous academic research, which is explicitly and unapologetically connected to political projects or movements." [9] (p. 1)

Being clear of aims, intentions and engagement styles when collaborating with partners is a key priority when beginning scholar-activist research. Gillan \& Pickrell [36] observe that a growing number of academics are claiming to employ these methodologies and urge academics to reflect on what we, as researchers, can give back to the social movements we engage with.

A scholar-activist collaborative approach with partners in the UK food movement can promote knowledge co-production and food change in three ways. Firstly, scholar-activists' use of participative and collaborative research methods enables the centering of people's voices from outside academia within knowledge production processes. This enables the disruption of hierarchies in knowledge production processes and acknowledges the value of reciprocal knowledge exchange within scholar-activist-partner relationships. Anderson \& McLachlan [7], People's Knowledge Editorial Collective [37], Wakeford \& Sanchez Rodriguez [6], Pimbert [5] and others highlight the importance of power and hegemony when engaged in research with partners. Academic researchers working within social movements can be seen to act in extractive ways that utilise the experiences and knowledge of social movements without empowering them to be fully realised partners within research processes. As Smith [38] states, "In PAR ... people who had previously been marginalised are able to designate the focus of the participatory and dialogue processes themselves". For effective participatory research, academics and partners need to consider "'Who has relevant knowledge?' and 'Who should have the power?'" [6] (p. 6). By creating research projects alongside partners, the voices and experiences of partners are foregrounded, which not only shapes research objectives, methodologies and project outputs, but also helps to break the divide between academic knowledge and people's knowledge.

Secondly, place-based food organisations and food policy assemblages are seeking to create food change. Scholar-activists such as Borras, who helped to establish La Via Campesina, can support these processes by blurring the boundaries of thinking and doing and taking action for political change [9]. A number of food scholars use Action Research methods to conduct food network research as they work alongside partners to generate food policy change. Blay-Palmer et al. [3] and Moragues-Faus and Sonnino [12] investigate City Region Food Systems and translocal initiatives that can create transformative city-based food programmes. Examples of such initiatives include The Milan 
Urban Food Policy Pact and SFCN. Across SFCN and Food Power programmes, place-based food organisations commonly draw in actors from local authorities, such as public health practitioners, local council officers, frontline service charities and others, who can input professionally sourced and funded evidence of local food, environment, community and health issues.

Thirdly, through this combined approach of disrupting knowledge hierarchies and working for food change, scholar-activists and partners are acting to promote a "politics of possibility" which challenges hegemonic logics [39]. A "politics of possibility" is, Gibson-Graham argue a new political and economic imaginary formed by place-based community self-organising. Describing this as a "globally emergent form of localized politics", Gibson-Graham sees creative, locally embedded movements as exemplars of "alternative economic activism" [39]. Whilst this case study explores the intersection of national food policy networks in a place-based food community, recent scholarship in this field has explored the interplay of networks across scales and within specific social, economic and geopolitical contexts as "food policy assemblages" [4,10]. The term food policy assemblages is used here to refer to national and translocal food policy organisations, such as SCFN and Food Power, that connect place-based food communities, along with the complex forces and contexts that shape them. The term food policy networks is also used in order to denote the specific linking of nodes of people or organisations acting together on issues of mutual concern. The case study explored here contributes to this scholarship by investigating how the processes and practices of place-based food communities act within the milieu of these assemblages, both drawing from resources and support given by national projects and building up a localised evidence base on "matters of concern" that shapes, in turn, the work of the wider network [40]. Intersected place-based national and translocal food policy assemblages enable self-organising civil society organisations to feed into evidence-gathering practices that are informed by the lived experiences of those effected by challenging food issues, whilst also being shaped by reports of best practices from linked organisations. This, in effect, scales up the potential reach of place-based food organisations' food advocacy and activism [3,29,39].

A challenge of scholar activism is the ability to navigate the tension between emotional engagement with partners and conducting rigorous research. The position of the researcher both within academia and within the partner organisations can result in the researcher being pulled in multiple directions through competing commitments. Croog, Hayes-Conroy et al. [41] propose addressing this by reflecting on the scholar-activist tools developed by Derickson and Routledge [42], who recommend balancing immersive research relationships with remaining firmly engaged within the academic community. By balancing the need to achieve partners' objectives, co-produce research outputs and respond to changing theoretical debates within academia, scholar-activists can triangulate their approach and manage potentially conflicting demands [42]. Croog and Hayes-Conroy [41] find Routledge and Derickson [43] concept of "situated solidarities" useful in navigating this complex research terrain, as it helps to revisit "the reflexivity question" and:

"... stimulate the creation of research encounters rooted in a sense of solidarity with and active participation in the work and political struggles of activists and marginalized groups." [41] (p. 1027)

Methodologically, scholar activism foregrounds processes that undermine knowledge hierarchies, such as facilitating the practising of science through methods that disperse power [5-7,41,42]. Croog, Hayes-Conroy et al. highlight that the "activism" within scholar activism involves the deployment of "active science" where knowledge generation processes are used as evidence for policy change [41]. The urgency of critical social and environmental issues, they argue, generates the need for researchers to work in collaboration with partners in order to achieve change. "Active science" therefore refers to the need for researchers to act alongside their partners in order to achieve change. It also refers to the adaptive, creative methods that are needed to tackle the range of complex issues that self-organising communities are addressing. The methods of co-producing knowledge can involve events or moments that enable both the progression of partners' interests and the gathering of data for research purposes. 
Scholar activism, by necessity, takes creative, deliberative and adaptive approaches to advance the partners' objectives. Responding to the partners' critical issues requires researchers to develop methods "that are not only playful but also political" [44] and deploy empowering and inclusive practices to produce insights into the participants' lived experiences; an approach that is particularly important when working with vulnerable and disadvantaged communities [41,42,44-46].

For many food scholars, food is a lens through which multiple challenges within communities can be investigated. This paper builds on recent literature that has focused on the rise of household food insecurity and food banking within the UK in response to the impacts of austerity, welfare reform and insecure employment $[27,28]$. Self-organising food communities are providing spaces of support and solidarity with people experiencing food insecurity [1,47]. Blake [1] investigated the impacts of self-organising communities who go beyond offering food aid by providing wider opportunities for "food-based resilience practices" [1] (p. 19), such as food pantries, free access to the internet and more. These practices attempt to address the intersecting consequences of poverty and food insecurity in communities with high multiple deprivation indices. Food banks offer care and solidarity "in the mean-time" argue Cloke, May and Williams [47], who acknowledge the limitations of the food aid sector and the need for "an anti-capitalist sea change to bring about more structural change" [47] (p. 707). Food banks, they argue, can "provide welfare and care in new and small ways", whilst offering solidarity and "being in-common with excluded groups" [47] (p. 719).

The next section investigates the processes and practices of a place-based food organisation and explores the role of scholar-activists in co-producing knowledge and co-convening a community of practice.

\section{Acting and Reflecting with the Food Movement: Methods of Engaging a Place-Based Food Community}

Exploring a case study of gathering evidence on household food insecurity in Exeter enables an investigation into the processes of knowledge co-production and scholar activism. In this section, the case study provides insights into the coalescing of linked organisations around a common interest, the growing issue of household food insecurity. As a scholar-activist, I was one of many actors involved in this knowledge co-creation process. After being awarded a small research fund, I was able to give my working time as well as some voluntary labour to support the project, including co-designing and taking part in the evidence gathering process in collaboration with Food Exeter's "Fair Access to Food Working Group" (FAF) members. After the case study has been set out, this section will reflect further on how the case study takes understandings of scholar activism further. A set of twinned analyses are explored here: findings from the FAF evidence-gathering project and findings from the processes of generating active science more broadly.

Established in 2014, and achieving charitable status in 2019, Food Exeter is a sustainable food city comprised of community-based organisations, local food producers, food retailers, food education organisations, charities, activists and faith-based organisations, as well as University of Exeter academics. Food Exeter aims to make sustainable and healthy food accessible to all in Exeter via both strategic policy change and city-based programmes focused on sustainable food provision, household food insecurity, attempts to boost the local food economy and more. Unlike many sustainable food cities organisations, Food Exeter operate independently of local authorities and deploy evidence generated by their projects to lobby for food policy and programme change at the strategic level of the city council.

My involvement with Food Exeter began in 2016, after convening an academic-practitioner symposium at West Town Farm, where I first met Food Exeter members. In the early days of my activity I took time to "find a role" and develop a sense of "being in the movement" [18]. Following Tornaghi \& Van Dyck [18] (p. 2), it is important to consider positionality as an activist academic:

"The marriage of being involved as both a scholar and activist in gardening issues raises questions as much on how to critically act in the creation of these spaces, as on how to tell research informed stories from below." 
To begin with, as an observer of steering group meetings, I prioritised listening and reflecting on the situated experiences of Food Exeter steering group members, many of whom worked directly in food and community projects in the city $[9,18]$. As an early career scholar, working with Food Exeter enabled me to establish and lead a research project, building on interests from my doctoral research. This engagement was funded by two small Economic and Social Research Council (ESRC) impact funding awards which supported Food Exeter's process in 2017 of developing a food strategy and their project in 2018 focused on gathering evidence on household food insecurity and food poverty in Exeter $[25,26]$. However, this position carries risk for the academic, as the funding only provided casual, short-term employment, which meant that long-term engagement required, at times, acting in a voluntary capacity. Acting as a scholar-activist also involves significant time taken in engaging with partners, which creates challenges in balancing the conflicting workload demands of political engagement and academic performance [48]. There is also risk for research partners in working closely with academics, as the short-term nature of funding cycles may limit academics' engagement, and the risk that academics may develop extractive research relationships that provide little benefit to partners.

\subsection{Acting with the Food Movement: Investigating Household Food Insecurity in Exeter}

Household food insecurity has become a rising concern in Exeter, as accessing adequate food has become a critical and urgent issue for many UK place-based food networks [1,26]. Food Exeter secured funding from Food Power in April 2018 to begin investigating household food insecurity in Exeter and initiate a collective multiagency response. Food Exeter's Fair Access to Food (FAF) working group led this process, and its members included representatives from The Exeter Diocese, Exeter Community Initiatives, St. Sidwell's Community Centre, Public Health Devon, The University of Exeter, community activists and volunteers. During 2018 FAF collected data that included gathering expertise from community-based agencies and people with lived experiences of household food insecurity. Knowledge was gathered via several strands, including: partner data, knowledge produced (on our request) by expert bodies such as Public Health Devon, an online survey with frontline service workers, interviews with Exeter Food Bank Clients, a preliminary workshop on mapping emergency food provision and the Exeter Food Poverty summit (see Table 1). As an academic, I was able to deploy institutional resources to support this project, including working with FAF members to undertake research with clients of The Exeter Food Bank, plus analysing all data gathered. This funding covered the costs of running The Exeter Food Poverty summit, printing materials and some of my time as a researcher on the project. My role included co-designing the research process, engaging with wider stakeholders and analysing the evidence gathered.

FAF members came together at working group meetings to collectively share institutional knowledge and co-design the process of knowledge co-production. Evidence was gathered by extending beyond core working group members to connect with a range of relevant bodies in Exeter whose work addresses issues of poverty and dietary ill-health in the city. Contributors to this process included actors representing a local authority organisation, faith-based organisations, activists and other community members. The evidence-gathering process began with a short online survey on food insecurity, targeted at organisations working with people at risk or experiencing food insecurity, asking "what does food poverty look like in Exeter?" City-based organisations who provided emergency food aid were then invited to a Fair Access to Food workshop. The workshop explored the factors preventing people from getting enough nutritious food and gathered ideas for what could be done at programme and strategic levels to promote positive change. The workshop also mapped the food support being provided in Exeter [49]. Partnering with Exeter Foodbank, 12 people who collected food parcels at the Mint Methodist church on two days in July 2018 were interviewed. Interviewees were asked about their circumstances and reasons for needing a Foodbank parcel; their experience of accessing the Foodbank and other support systems; their experience of the benefits system; their ideas for preventing the need for Foodbank parcels and ways to improve support to people in food need. In November 2018 Food Exeter held a Food Poverty summit where initial research findings were shared by myself 
and Food Exeter's coordinator and group discussions contributed to the evidence-gathering process. Agencies invited included health, social care and community organisations, as well as schools, children and youth services, churches, local councillors, the University and College, local food producers and colleagues from other food poverty partnerships. Participants shared their experiences and ideas on the themes of what is causing food poverty and how best to respond, how best to tackle child hunger and malnutrition and how best to meet the food needs of vulnerable adults (see Table 1).

Table 1. Exeter Fair Access to Food Knowledge co-production: Processes, Participants and Outputs.

\begin{tabular}{|c|c|c|c|}
\hline $\begin{array}{c}\text { Knowledge } \\
\text { Co-Production Process } \\
\end{array}$ & $\begin{array}{l}\text { Participant } \\
\text { Numbers }\end{array}$ & Typology of Participants & Outputs \\
\hline $\begin{array}{l}\text { Targeted Network } \\
\text { Questionnaire }\end{array}$ & 13 & Frontline and charity services & Survey Results \\
\hline $\begin{array}{l}\text { Interviews with People } \\
\text { with Lived Experiences } \\
\text { of Food Insecurity }\end{array}$ & 12 & Exeter Food Bank (EFB) clients & Interview transcripts \\
\hline $\begin{array}{l}\text { Emergency Food } \\
\text { Workshop }\end{array}$ & $\begin{array}{c}18 \text { people/ } \\
17 \text { organisations }\end{array}$ & $\begin{array}{c}\text { Emergency and community food } \\
\text { providers and interested } \\
\text { professionals }\end{array}$ & $\begin{array}{l}\text { Co-produced map of } \\
\text { emergency food aid in Exeter }\end{array}$ \\
\hline $\begin{array}{l}\text { Exeter Food Poverty } \\
\text { Summit }\end{array}$ & $\begin{array}{c}55 \text { people/ } \\
35 \text { organisations }\end{array}$ & $\begin{array}{l}\text { Varied: Community services, } \\
\text { Local Authorities, Food Exeter } \\
\text { network, Regional Food Power } \\
\text { members, others }\end{array}$ & $\begin{array}{l}\text { Co-produced group notes on } \\
\text { suggested next steps of action } \\
\text { to support: Vulnerable Adults, } \\
\text { Children and Families, } \\
\text { Low-Income Adults }\end{array}$ \\
\hline Partner Data Collection & & $\begin{array}{l}\text {-Public Health Devon (PHD) Data } \\
\text {-Exeter Food Bank (EFB) Data } \\
\text {-Food Power Peer Learning } \\
\text {-regional, national meetings and } \\
\text { peer reports }\end{array}$ & $\begin{array}{c}\text {-Mapping areas of deprivation } \\
\text { in Exeter } \\
\text {-Data on numbers of people } \\
\text { accessing the food bank } \\
\text {-Sharing best practices }\end{array}$ \\
\hline
\end{tabular}

The emergency food mapping workshop and Exeter Food Poverty summit were both interactive events with invited participants whose organisations addressed, or had interests in, the issues of household food insecurity both in Exeter and regionally. At these events, knowledge was co-produced via facilitated group sessions. I coded and analysed all materials gathered across the knowledge co-production processes, and the findings were presented in our co-written report "Food Poverty in Exeter: Steps for Positive Change" [26]. The FAF process brought together actors representing a range of place-based organisations to form a community of practice that gathered evidence on the issue of household food insecurity in Exeter. Whilst some members of the working group were active with Food Exeter prior to the FAF process, others joined the working group as part of the knowledge co-production process. Evidence-gathering events opened the process up to city-wide organisations and individuals, who contributed knowledge and experiences at the emergency food workshop, EFB client interviews and Exeter Food Poverty Summit. The FAF process enabled cross-sectoral actors to link together and share knowledge and experiences of household food insecurity in Exeter. For many operating with limited capacities, this process was an opportunity to take a cross-city approach to begin to consider household food insecurity as a collective force. The FAF process benefited from the South West Food Power regional alliance, formed with other place-based food communities addressing household food insecurity. The regional alliance met and shared best experiences throughout the duration of the 2018 FAF project, enabling opportunities for peer learning and support. The regional alliance also strengthened the impact of the FAF process, as regional and national actors attended and spoke at The Exeter Food Poverty summit. For example, a presentation by CATERed (a co-operative trading company jointly owned by local schools and Plymouth city council) at a regional Food Power event hosted by Food Plymouth provided insights into their significant holiday hunger food provision in Plymouth during school holidays. The presentation highlighted the differences in political structures between the Exeter and Plymouth city councils and the close links CATERed have with Plymouth city council. CATERed were subsequently invited to speak at The Exeter Food Poverty summit, which 
helped to develop understandings of opportunities and barriers to promoting fair access to food for all in Exeter. In particular, it provided Food Exeter members with ideas on how to boost the supply of local produce to Devon schools and build a wider response to holiday hunger [50].

Findings gathered during the FAF process included data from EFB that highlighted the rising crisis of household food insecurity in the city:

"The number of emergency food parcels provided by EFB has risen continually each year and has increased by $138 \%$ since 2012/13. In 2018/19, the foodbank provided three days' worth of emergency food to 6878 people, of which 2158 were children". [See Appendix B-V]

In conjunction with these food poverty statistics, health indicators related to diet in Exeter were also concerning. Almost $30 \%$ of children at age 10-11, and more than half of adults, were overweight or obese. Over a third of adults were not eating the recommended 5 daily doses of fruit and vegetables, and deprived Exeter wards had the highest density of fast food outlets in Devon [see Appendix B-VI]. Interviews with participants with lived experiences of food insecurity identified that benefit changes, driven by a welfare reform that included the roll-out of universal credit, and precarious employment were the key causes of everyday food insecurity and the need for emergency food aid. Benefit issues and precarious employment led participants with low incomes to vulnerable positions, that required additional services relating to mental and general ill health, precarious accommodation, homelessness and food poverty. These findings have been disseminated as a FAF project report, co-written by the author and Food Exeter's coordinator [26] and shared with local decision-makers in Exeter and Devon, Food Exeter network members and our national partners Food Power and The Sustainable Food Cities network.

\subsection{Reflecting on the Food Movement: Co-Convening a Community of Practice}

A central component of an effective community of practice that responds to dynamic food politics is to create an active working network of collaborators. Food Exeter's 2018 FAF project utilised a range of tools to enable knowledge co-production that harnessed the knowledge, expertise and experiences of a broad community. Deploying a series of engagement approaches, including regular meetings, one-off workshops and events, as well as regular communication via email newsletters, formed the process of co-convening a responsive network. The role of Food Exeter's coordinator was central in the network formation, as she took time to have one-to-one meetings with key working group members to fully understand their professional roles and the knowledge they had access to. Through this engagement process, Public Health Devon developed a dashboard of food poverty indicators in Devon that showed the challenges in Exeter of high levels of homelessness, high densities of fast food outlets, high levels of children living in low-income families and high levels of fuel poverty (see Appendix A). In addition, the FAF working group developed closer working relationships with Exeter Food Bank (EFB), including interviewing clients and talking to volunteers. Testimonies gathered from Exeter Food Bank clients provided critical insights of their lived experiences of household food insecurity and the challenges that led to accessing food aid. An EFB volunteer worker subsequently joined the FAF working group and shared regular updates on EFB activity, up-to-date data from the food bank and the wider food aid sector in Exeter. Figure 1 sets out a typology of the roles of actors within this place-based community of practice, highlighting the importance of local authority and frontline charities in informing the knowledge co-production process. The input of a spectrum of expert knowledge, which included professional bodies, community members and those with lived experiences of household food insecurity, was essential to acquiring knowledge of household food insecurity in Exeter. It is notable that those with lived experiences of household food insecurity played a limited role in the community and knowledge co-production processes, as Exeter Food Bank clients were interviewed but did not participate further in the process. Food Bank interviewees were invited to provide a recorded testimony for the Exeter Food Poverty summit. Whilst several Food Bank clients initially indicated a willingness to publicly share their experiences, they ultimately did not come 
forward. A more established relationship between Food Exeter and the Food Bank clients may have facilitated a deeper involvement of Food Bank clients in the project. Time pressures of Food Exeter staff contributed to the limited involvement of Food Bank clients. The importance of inclusion is acknowledged by Food Exeter and Food Power, which has funded food power alliances to undertake projects that encourage the involvement of those with lived experiences in the decision-making practices of place-based food networks. Taking an inclusive approach to community-informed food policies and programmes requires significant commitments over time for developing an effective engagement process [51,52].

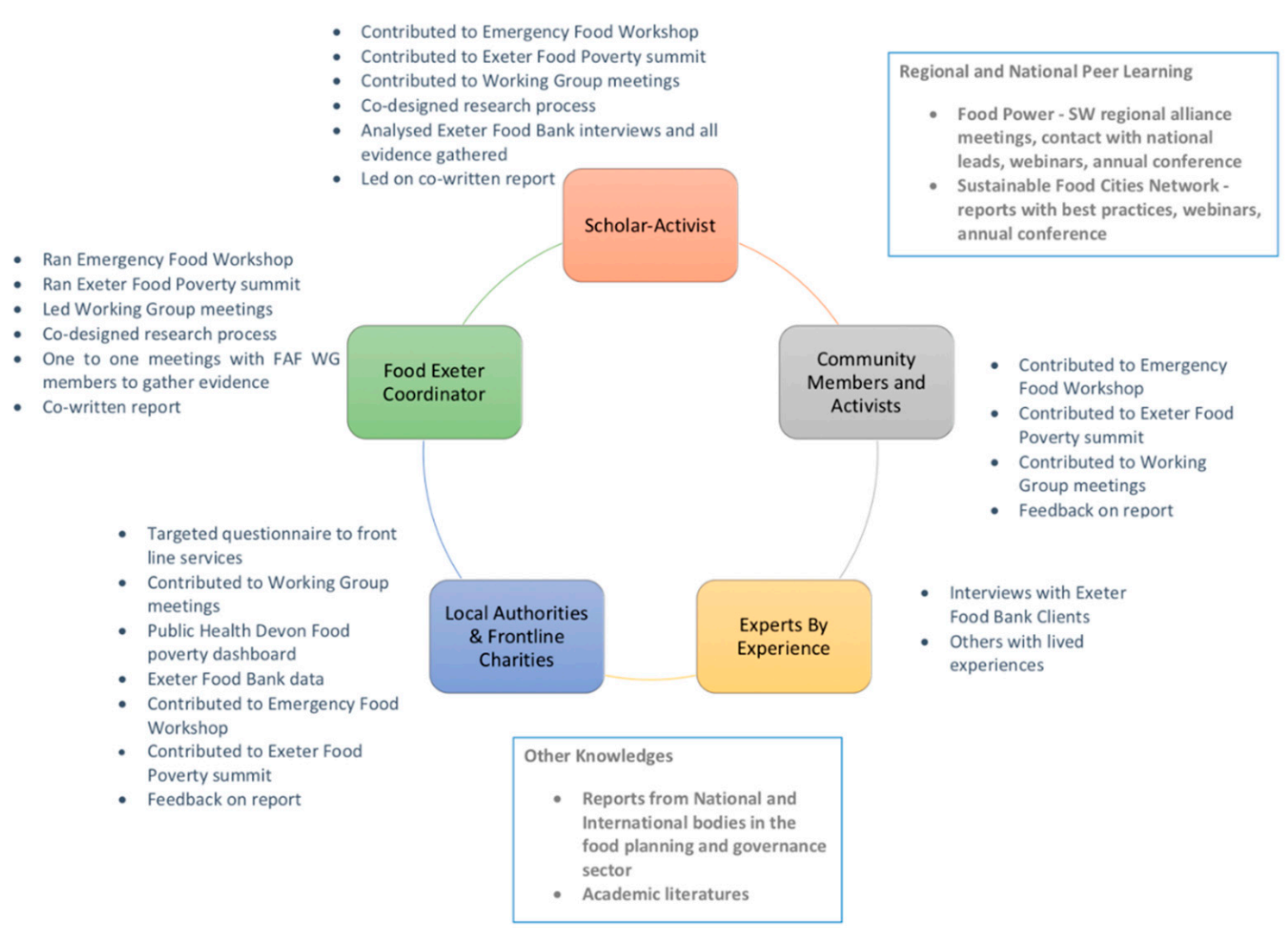

Figure 1. Actors co-producing knowledge in a Place-Based Food Community of Practice.

From the perspective of a scholar-activist, research findings from the Exeter Fair Access to Food Project generated wider insights on the operations of a place-based food community and the challenges and tensions of working with the food movement. These reflections were produced by taking a step back and analysing the notes produced during the collaborations and participant observation. Self-organising food communities may experience the challenges of financial insecurity, a lack of institutional support for implementing projects and the reliance on voluntary input from linked organisations and community members. Time taken to apply for, and secure, funding is a significant challenge for self-organising food communities, that can disrupt the development of projects and cross-city engagement. Funding awards often focus on project delivery and may not include core funds for coordination. This can produce extra work for members of boards, steering groups or trustees as they attempt to implement projects without adequate support. The lack of long-term funding for coordination impacted Food Exeter's ability to capitalise on the cross-city momentum generated by the FAF project, as the coordinator left at the end of the project, partly due to job insecurity. The turnover of paid staff, plus the loss of several long-term steering group members who stepped down at this time, resulted in a loss of impetus for the second stage of the FAF project Another challenge noted prior to the start of the FAF project was a tension between Food Exeter steering group members whose 
prime focus was on boosting the local food economy and those concerned with access to nutritious food for all. Debates on which should take priority in the roll-out of projects was a common feature of meetings at that time [25]. After the successful operation of the FAF project and the engagement with local food producers on increasing access to local and nutritious food for all, this tension was no longer evident at meetings. After the FAF project, a significant crossover between the aims of the Fair Access to Food and Routes to Market working groups was evident in their projects [see Appendix B-VII].

Food Exeter operated independently of local authorities, including the city council. Therefore, their efforts to effect change lacked the support of local decision-makers. Part of this challenge was due to the fact that the political structure of local authorities in Devon, as Exeter city council, operates within a two-tier local authority system, and therefore has the status of a district council. This contrasts with the unitary authority, Plymouth city council, with the result that responsibilities for public health are held at the wider county level rather than at the city level, in Exeter. Whilst bodies such as Public Health Devon took interest in the work of Food Exeter, their participation was limited in part due to their wider geographic responsibilities. Meanwhile, whilst individuals within Exeter city council had interest in the work of Food Exeter, Exeter city council's limited responsibilities for public health, plus reductions in their grant from central government, may have contributed to their lack of engagement.

\section{Discussion: The Formation of a Knowledge Co-Production Network}

Active science underpinned the mechanisms that led to Food Exeter co-producing knowledge on household food insecurity in Exeter. Active science involves using collaborative and adaptive knowledge-gathering practices, which in this case included regular working group meetings, the Emergency Food workshop, the Exeter Food Poverty summit and data gathered from partners, such as Public Health Devon's Food Poverty Dashboard and Exeter Food Bank's data on people using the food bank $[26,41]$. Moments of active learning arose through a multi engagement process that furthered the development of organisational linkages and knowledge co-production. Figure 1 highlights the central role of Food Exeter's coordinator in leading this process, gathering data and co-convening a community of practice to gather around a pressing issue of concern. Without this funded position, Food Exeter, myself and other interested bodies would have lacked the capacity to gather evidence on household food insecurity in Exeter. Working closely with the coordinator as a scholar-activist, I was able to co-design the research process, support and advise the coordinator, co-convene the community of practice, lead on analysing evidence gathered and co-produce a report for dissemination to interested stakeholders.

A scholar-activist approach to researching food communities affords academics opportunities to adopt positionalities that traverse boundaries between community engagement, solidarity work, advocacy and knowledge generation. Within academia, scholar activism reduces knowledge hierarchies between research participants and the researcher. This engaged methodology enables the generation of co-produced knowledge grounded in experience. Working within a PAR tradition, this engaged process sought to co-produce knowledge as well as build a movement equipped to address the critical issues of hunger in a 21st Century UK city [1]. When taking a scholar-activist approach, the research process and the development of the partner's project are closely intertwined. The scholar operates within the partner's project, assisting and co-producing knowledge which boosts the partner's capacity to effect change [5-7,37]. By adopting this practice, the researcher gains in-depth insights into the operating of the partner organisation, including the challenges and opportunities faced by self-organising place-based food networks.

“The 'research' part of the project was thus not an isolated effort, but organically integrated into the participants' political organizing and movement building work ... the connection between the PAR project and the movement-building work was clear" [53] (p. 26)

Investigating the FAF household food insecurity process highlighted how a scholar-activist can act as a lever in co-producing knowledge through processes of active science and co-convening a community of practice [2,41]. Within the place-based food community, a scholar-activist provides expertise in 
rigorous knowledge production that is valued in many settings, including academic and policy-making sectors. This expertise means that academics can play a core role in a place-based community of practice. The expertise of others, such as frontline charities, food producers, community cafes, emergency food aid organisations, local authorities and others, are also vital within a community of practice working to address household food insecurity. The present case study underscores the iterative and adaptive practices required to work alongside the food movement. Supporting an active science process required the scholar-activist to adopt a range of approaches: listening, thinking, doing, acting and reflecting with partners, which generated an iterative cycle of knowledge co-production (see Figure 2). A scholar-activist acts as a lever between the nested scales within food policy assemblages by helping a community of practice to form and take action to co-produce evidence of food issues. The scholar-activist is able to link a place-based community of practice with actors leading national programmes addressing household food insecurity. This linking process assists the gathering of knowledge of best practices and supports the co-production of shareable outputs that provide evidence for critical food, health and environmental issues facing many UK communities. Through these roles, a scholar-activist can bridge policy and praxis and assist the place-based food community promote local policy change (see Figure 2). In contrast to other research practices, the scholar-activist is supporting and lending their expertise to research partners, rather than directing a research process that partners have limited control over. Through scholar-activist methodologies, knowledge can be harnessed from partners and co-produced in order to generate timely policy interventions as well as insights for academia. Whilst the active methods set out in Figure 2 are responsive to this specific project, they include positions that are recommended when conducting scholar-activist methods with partners $[9,18,41]$.

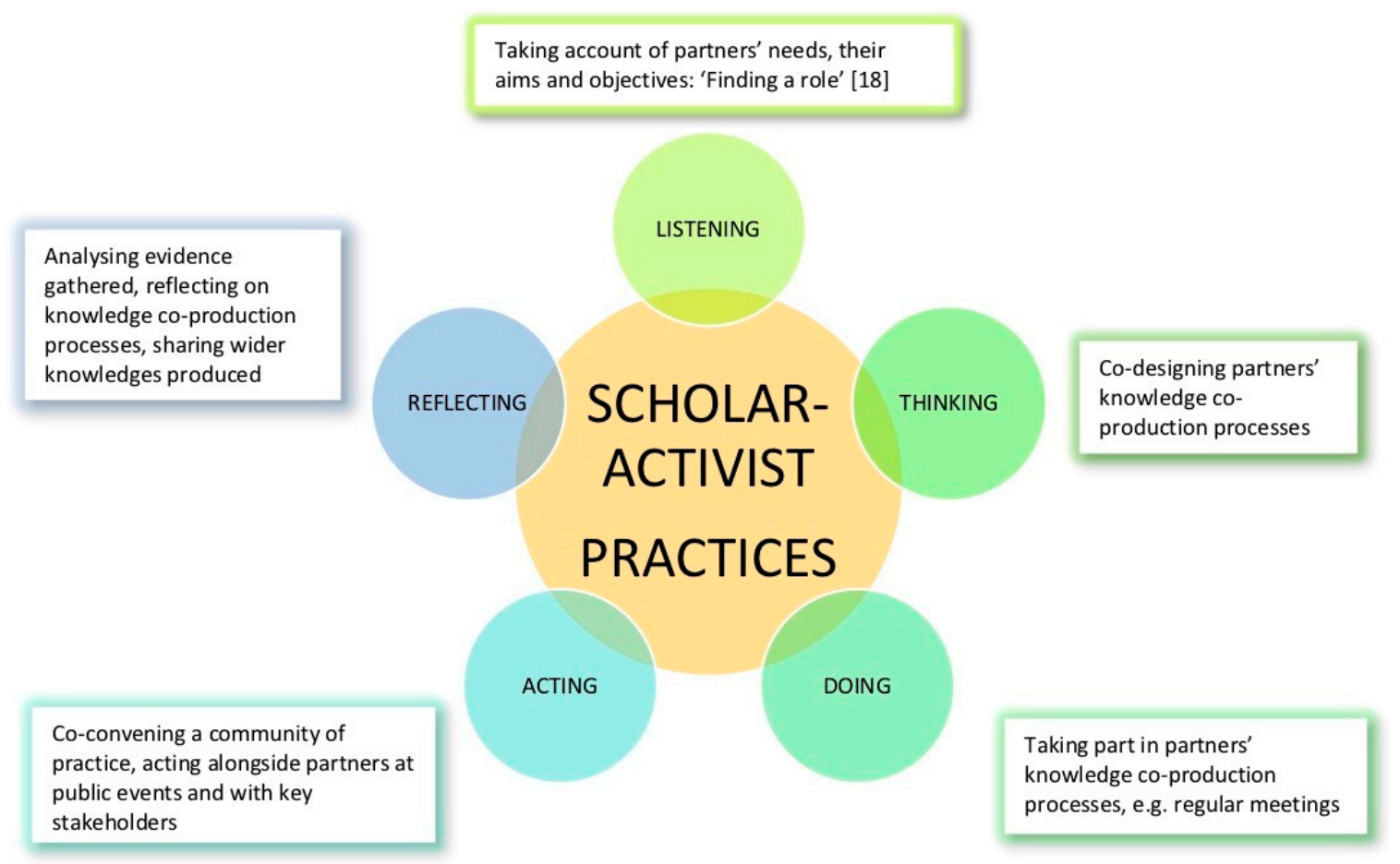

Figure 2. Scholar-activist practices for Knowledge Co-production with Partners.

Funding is a central resource within social movements that fuels the generation of substantive activity to address key issues. Food Power and their time-limited "Food Poverty Alliance" funding provided the context within which Food Exeter's FAF project unfolded. This supported place-based action by employing a coordinator and providing linkages to nation-wide funded projects with similar objectives. Without this funding and support, the FAF project would not have taken place. In addition, Food Power provided peer-mentoring and knowledge exchange at regional and nation-wide scales, an assistance that 
developed in the context of the FAF project. This multisector food policy assemblage enabled the FAF project to be informed by a range of knowledges at place-based regional and national scales.

\section{Conclusions}

An analysis of the typology of processes, actors and networks forming the knowledge co-production process provides insights into the workings of a place-based food community operating within food policy assemblages [4]. Gathering a range of expert knowledge enabled a place-based food community to form a community of practice generating evidence-based insights into the challenge of household food insecurity in Exeter. In the current vacuum of adequate food policies in England and the context of the negative impacts of welfare reform in the UK, this is an important process in taking steps to document and then address this critical issue at a place-based scale. This case study provides an insider perspective on the formation of a community of practice working to effect place-based action on household food insecurity, operating within a wider food policy assemblage.

Scholar activism within the food movement enables the co-production of knowledge and the generation of active science, which supports the development of self-organising food communities and their engagement with actors within wider food policy assemblages $[4,41]$. This study has highlighted the potential for meaningful engagement with a food movement via a scholar-activist approach, affording opportunities for in-depth understandings of the situated challenges and processes underpinning the roll-out of a programme of action. Food Exeter's FAF project provided an example of reciprocal knowledge generation between academic, community-based and local authority partners who were able to co-produce knowledge in a timely response to an urgent issue. Food Exeter's Fair Access to Food case study highlighted that household food insecurity is a growing and critical issue in the UK $[27,28,54]$. Being able to respond to an urgent need for knowledge is challenging for academics working within the constraints of higher education funding cycles, and this challenge is heightened for early career researchers. Existing collaborative relationships, alongside responsive internal university funding, were vital in this case study as the basis for an urgent response to investigate household food insecurity in Exeter. Scholar-activist and PAR research methodologies require long-term engagement with partners [6,8,36,37]. Academics involved in research, report writing, grant writing and governance forming practices with partners are recurrently sharing their expertise and specialist networks. An approach that may be lauded by higher education institutions in terms of its impact agenda, but one that requires a greater understanding of the time and labour commitments that can impact academic outputs.

The food movement is an accessible space where scholars can act to make a difference. In this study, scholar activism can be seen as a form of "quiet activism", as the scholar is acting within settings that operate with familiar working practices, such as keeping records, using transparent and accountable decision-making practices and more [30,32]. By co-convening a place-based food community, the scholar-activist is working with other community members, including local authority and frontline charities, who are all seeking to effect food policy and programme change. Within the context of national austerity policies, making a difference at a place-based scale opens up the possibility for local policies and programmes to address the effects of challenges in accessing welfare and housing. However, as Blake [1] makes clear, there are limitations to the changes a self-organising community of practice can make, as

“... there is a specific neoliberal context that increases the need for self-organising as a means of creating resilience capacity around food." [1] (p. 18)

At the time of writing, the impacts of Food Exeter's FAF process include the linking up of the food aid sectors in Exeter to ensure that the knowledge and awareness of emergency food services is up to date and carry on working towards establishing a cross-city food poverty alliance. The evidence-gathering process co-produced new knowledge of the scale and seriousness of household food insecurity in Exeter, as well as the issues causing it. 
By investigating "how to critically act" as an academic [18], this paper has set out a typology of the knowledge deployed in place-based action on food insecurity that operates within multisector, multiscale food policy assemblages. It highlights the importance of including a range of voices and backgrounds when academics investigate and support action taken on food justice. A scholar-activist approach, where the researcher is embedded within the partner organisation, enables researchers to more fully understand the situated realities of complex issues facing communities and work to progress "a politics of possibility" in terms of place-based food policy and programme change [39]. Working alongside partners allows academics to understand the sensitivities of engaged, collaborative research and the need for "situated solidarities" as a lever to promote change [43]. By "blurring the boundaries between thinking and doing" [9], scholar-activist and other PAR methods help to break down the boundaries between scientific and popular knowledge, an essential step for understanding the situated experiences of place-based communities generating action to address complex issues of food justice.

Funding: This research was funded by ESRC Impact Acceleration Award 110666R from the University of Exeter. The APC was funded by The University of Exeter's Open Access Fund.

Acknowledgments: I would like to acknowledge the support of Food Exeter, Food Power and SFCN personnel in collaborating on this project. I appreciate the support of Stewart Barr and Harry West at The University of Exeter for this and a previous project with Food Exeter. I am grateful to the support of Moya Kneafsey and Mustafa Hasanov for feedback on the original draft of this paper and to the very helpful comments from anonymous peer reviewers.

Conflicts of Interest: The author declares no conflicts of interest. The funders had no role in the design of the study, in the collection, analyses or interpretation of data, in the writing of the manuscript or in the decision to publish the results.

\section{Appendix A}

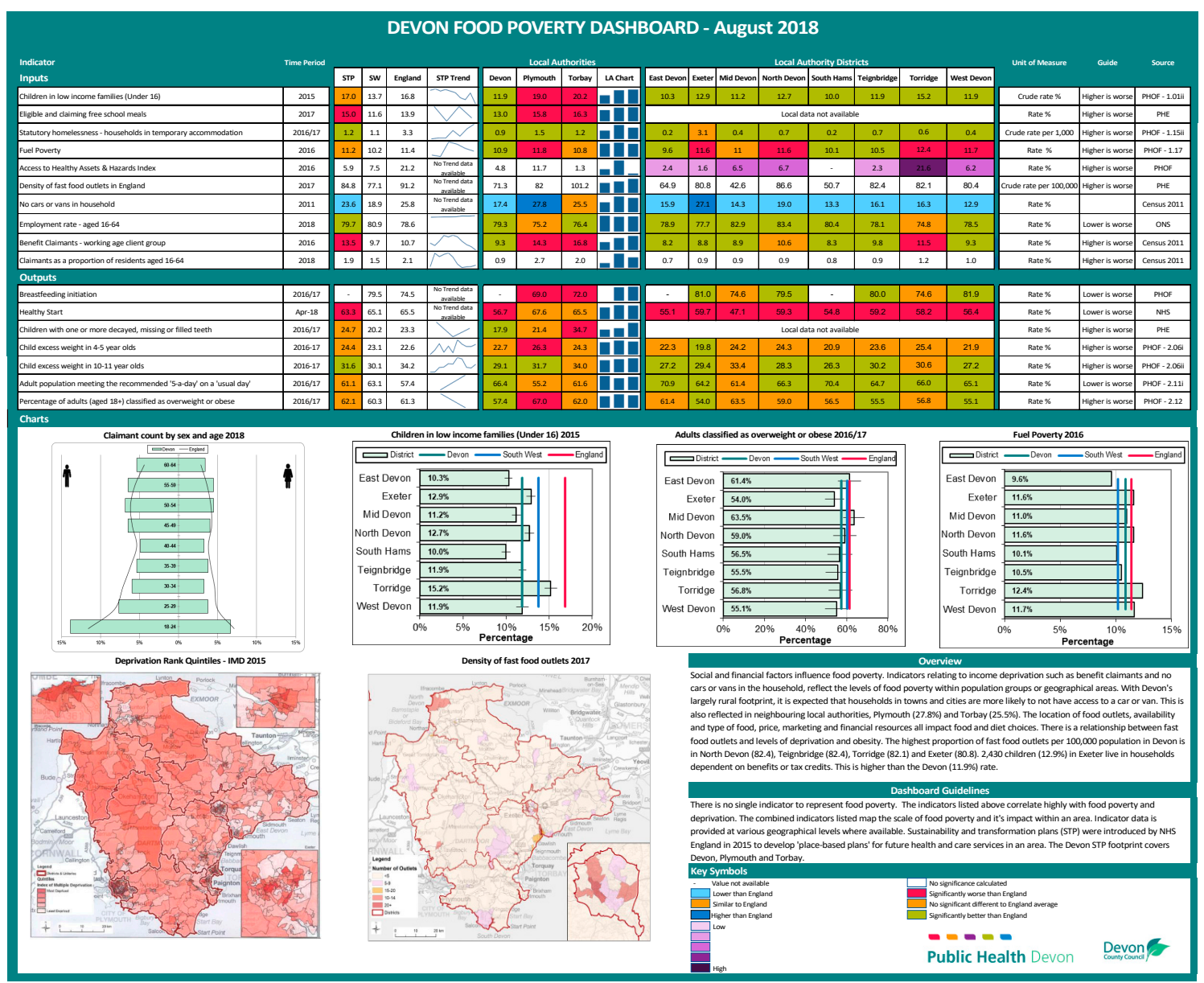

Figure A1. Public Health Devon (2018) Devon Food Poverty Dashboard. 


\section{Appendix B Endnotes on Food Policy Organisations}

I. For more information and insights into different food governance approaches within the UK see the work of Nourish Scotland, Welsh Food Poverty Network and Food Sense Wales. At time of writing Defra's National Food Strategy is out for consultation and there is hope that this will work towards an effective food policy in England.

II. Usage here of 'The Sustainable Food Cities Network (SFCN)' denotes the UK wide body (plus Cork, Ireland) that supports the work of individual Sustainable Food Cities. 'SFCN' refers to the national body, whereas the term 'Sustainable Food Cities' refers to the actions of individual civil society food networks signed up to the SFCN aims. Note the term 'Sustainable Food Cities' includes civil society food networks operating under a range of political structures that include boroughs, cities, unitary authorities, regions and counties. From April 2020 SFCN is now known as 'The Sustainable Food Places'.

III. Food Power work with communities across the UK to support coordinated approaches to tackling food poverty in over 50 place-based projects. The four-year programme is funded by The National Lottery Community Fund and is led by Sustain and Church Action on Poverty),

IV. Food Exeter's working group on household food insecurity is called the 'Fair Access to Food' working group. Food Exeter and linked organisations commonly refer to household food insecurity as 'food poverty' and their summit was known as 'The Exeter Food Poverty summit'. Therefore, whilst the term household food insecurity is generally used in this paper, I also refer to food poverty to acknowledge the term my research partners recognise.

V. Statistics on the number of customers accessing Food Bank services in Exeter are provided by research partners -Exeter Food Bank.

VI. Statistics on Food Poverty in Exeter were provided by research partners -Public Health Devon: Devon Food Poverty Dashboard 2018 -see Appendix A.

VII. Food Exeter is now a charity and is operating on a modified model. Instead of consisting of a steering group and working group, it now has a small board of trustees and a wider advisory group, along with several part-time paid consultants, volunteers and two very active working groups: "Fair Access to Food" and "Routes to Market". They are, at the time of writing, investigating the potential for a cross-city "Fair Access to Food Alliance". For the latest updates check their website.

\section{References}

1. Blake, M.K. More than Just Food: Food Insecurity and Resilient Place Making through Community Self-Organising. Sustainability 2019, 11, 2942. [CrossRef]

2. Moragues-Faus, A.; Morgan, K. Reframing the foodscape: The emergent world of urban food policy. Environ. Plan. Econ. Space 2015, 47, 1558-1573. [CrossRef]

3. Blay-Palmer, A.; Sonnino, R.; Custot, J. A food politics of the possible? Growing sustainable food systems through networks of knowledge. Agric. Hum. Values 2016, 33, 27-43. [CrossRef]

4. Santo, R.; Moragues-Faus, A. Towards a trans-local food governance: Exploring the transformative capacity of food policy assemblages in the US and UK. Geoforum 2019, 98, 75-87. [CrossRef]

5. Pimbert, M. Agroecology and food sovereignty: Charting a way to a radical transformation of the food system. In Politics of Food; Sternberg Press: Berlin, Germany, 2019; pp. 86-97.

6. Wakeford, T.; Rodriguez, S.J. Participatory action research: Towards a more fruitful knowledge. In Connected Communities Foundation Series; Facer, K., Dunleavy, K., Eds.; University of Bristol/AHRC Connected Communities Programme: Bristol, UK, 2018.

7. Anderson, C.R.; McLachlan, S.M. Transformative research as knowledge mobilization: Transmedia, bridges, and layers. Action Res. 2016, 14, 295-317. [CrossRef]

8. Kindon, S.; Pain, R.; Kesby, M. (Eds.) Participatory Action Research Approaches and Methods: Connecting People, Participation and Place; Routledge: London, UK, 2007.

9. Borras, S.M. Land Politics, Agrarian Movements and Scholar-Activism. Inaug. Lect. 2016. Erasmus University. Available online: https://repub.eur.nl/pub/93021/ (accessed on 4 February 2019). 
10. McFarlane, C. Translocal assemblages: Space, power and social movements. Geoforum 2009, 40, 561-567. [CrossRef]

11. Sonnino, R.; Marsden, T.; Moragues-Faus, A. Relationalities and convergences in food security narratives: Towards a place-based approach. Trans. Inst. Br. Geogr. 2016, 41, 477-489. [CrossRef]

12. Moragues-Faus, A.; Sonnino, R. Re-assembling sustainable food cities: An exploration of translocal governance and its multiple agencies. Urban Stud. 2019, 56, 778-794. [CrossRef]

13. SFCN Website-'Key Issues'. Available online: http://www.sustainablefoodcities.org/keyissues (accessed on 10 January 2019).

14. Guthman, J. Neoliberalism and the making of food politics in California. Geoforum 2008, 39, 1171-1183. [CrossRef]

15. DuPuis, E.M.; Goodman, D. Should we go home to eat: Toward a reflexive politics of localism. J. Rural Stud. 2005, 21, 359-371. [CrossRef]

16. Bristol Food Policy Council. Available online: https://bristolfoodpolicycouncil.org (accessed on 12 December 2019).

17. Brighton \& Hove Food Partnership. Available online: https://bhfood.org.uk (accessed on 12 December 2019).

18. Tornaghi, C.; Van Dyck, B. Research informed gardening activism: Steering the public food and land agenda. Local Environ. 2015, 20, 1247-1264. [CrossRef]

19. Ostrom, E. Crossing the great divide: Coproduction, synergy, and development. World Dev. 1996, 24, 1073-1087. [CrossRef]

20. Bovaird, T. Beyond engagement and participation: User and community coproduction of public services. Public Adm. Rev. 2007, 67, 846-860. [CrossRef]

21. Jasanoff, S. (Ed.) States of Knowledge: The Co-Production of Science and the Social Order; Routledge: London, UK, 2004.

22. The Climate and Development Knowledge Network. Co-Producing Climate Knowledge-Great in Theory, but How about Practice? 2018. Available online: https://cdkn.org/2018/03/feature-co-production/?loclang= en_gb (accessed on 18 March 2020).

23. Wenger, E.; Dermott, R.; Snyder, W.M. Cultivating Communities of Practice; Harvard Business Review Press: Brighton, MA, USA, 2002.

24. Communities of Practice' See Learning Theories. Communities of Practice. 2014. Available online: https://www.learning-theories.com/communities-of-practice-lave-and-wenger.html (accessed on 18 March 2020).

25. Food Exeter. A Food Strategy for Exeter: Rediscovering and Redeveloping Localised Food Systems. Available online: http://geography.exeter.ac.uk/documents/Food_Exeter_Strategy_2017-Cultivating_Food_leaflet.pdf (accessed on 10 October 2019).

26. Sandover, R.; Food Exeter. Food Poverty in Exeter: Steps for Positive Change. Available online: https://foodexeter.org.uk/wp-content/uploads/Food_Exeter_Food_Poverty_report_2019-1.pdf (accessed on 10 October 2019).

27. Lambie-Mumford, H.; Dowler, E. Rising use of food aid in the United Kingdom. Br. Food J. 2014, 116, 1418-1425. [CrossRef]

28. Loopstra, R.; Reeves, A.; Tarasuk, V. The rise of hunger among low-income households: An analysis of the risks of food insecurity between 2004 and 2016 in a population-based study of UK adults. J. Epidemiol. Community Health 2019, 73, 668-673. [CrossRef] [PubMed]

29. Chatterton, P.; Pickerill, J. Everyday activism and transitions towards post-capitalist worlds. Trans. Inst. Br. Geogr. 2010, 35, 475-490. [CrossRef]

30. Kneafsey, M.; Owen, L.; Bos, E.; Broughton, K.; Lennartsson, M. Capacity Building for Food Justice in England: The Contribution of Charity-led Community Food Initiatives. Local Environ. 2018, 23, 621-634. [CrossRef]

31. Pottinger, L. Planting the seeds of a quiet activism. Area 2017, 49, 215-222. [CrossRef]

32. Wadsworth, Y. What is participatory action research?', Action Research International. In Participatory Action Research Approaches and Methods: Connecting People, Participation and Place; Routledge: London, UK, 2007.

33. Smith, J.; Jehlička, P. Quiet sustainability: Fertile lessons from Europe's productive gardeners. J. Rural Studies 2013, 32, 148-157. [CrossRef]

34. The Guardian-How Extinction Rebellion Put the World on Red Alert. 2019. Available online: https:/www.theguardian.com/environment/2019/oct/06/how-extinction-rebellion-put-world-onred-alert-year-since-it-was-founded (accessed on 10 October 2019). 
35. Koirala-Azad, S.; Fuentes, E. Introduction: Activist scholarship-possibilities and constraints of participatory action research. Soc. Justice 2009, 36, 1.

36. Gillan, K.; Pickerill, J. The difficult and hopeful ethics of research on, and with, social movements. Soc. Mov. Stud. 2012, 11, 133-143. [CrossRef]

37. People's Knowledge Editorial Collective (Ed.) Everyday Experts: How People's Knowledge Can Transform the Food System, Reclaiming Diversity and Citizenship Series; Coventry University: Coventry, UK, 2017.

38. Smith, L.T. On tricky ground: Researching the native in the age of uncertainty. In The Landscape of Qualitative Research; Denzin, N.K., Lincoln, Y.S., Eds.; Sage: Thousand Oaks, CA, USA, 2007; pp. 85-113.

39. Gibson-Graham, J.K. A Postcapitalist Politics; University of Minnesota Press: Minneapolis, MI, USA, 2006.

40. Latour, B. Why has critique run out of steam? From matters of fact to matters of concern. Crit. Inq. 2004, 30, 225-248. [CrossRef]

41. Croog, R.; Hayes-Conroy, A.; Guiterrez-Velez, V.H.; Montoya, A.S. Real World Food Justice and the Enigma of the Scholar-Activist Label: A Reflection on Research Values. ACME Int. E-J. Crit. Geogr. 2018, 17, 1512.

42. Derickson, K.D.; Routledge, P. Resourcing Scholar-Activism: Collaboration, Transformation, and the Production of Knowledge. Prof. Geogr. 2014, 67, 1-7. [CrossRef]

43. Routledge, P.; Derickson, K.D. Situated solidarities and the practice of scholar-activism. Environ. Plan. D Soc. Space 2015, 33, 391-407. [CrossRef]

44. Bagelman, J.; Nunez Silva, M.A.; Bagelman, C. Cookbooks: A tool for engaged research. GeoHumanities 2017, 3, 371-395. [CrossRef]

45. Brown, K.; Eernstman, N.; Huke, A.R.; Reding, N. The drama of resilience: Learning, doing, and sharing for sustainability. Ecol. Soc. 2017, 22. [CrossRef]

46. Pratt, G.; Kirby, E. Performing Nursing: BC Nurses' Union Theatre Project. ACME Int. J. Crit. Geogr. 1969, 2, 1.

47. Cloke, P.; May, J.; Williams, A. The geographies of food banks in the meantime. Prog. Hum. Geogr. 2017, 41, 703-726. [CrossRef]

48. FAQs: Frequently Asked Questions on Being a Scholar/Activist. In Engaging Contradictions: Theory, Politics and Methods of Activist Scholarship; University of California Press: Berkeley, CA, USA, 2015; pp. 341-366.

49. Food Exeter's 'Food Support in Exeter' Map. Available online: https://foodexeter.org.uk/what-we-do/fairaccess-to-food/ (accessed on 10 October 2019).

50. Brad Pearce of CaterEd's presentation for Food Exeter. Available online: https://foodexeter.org.uk/wpcontent/uploads/Brad-Pearces-presentation.pdf (accessed on 10 October 2019).

51. Hebinck, A.; Page, D. Processes of participation in the development of urban food strategies: A comparative assessment of Exeter and Eindhoven. Sustainability 2017, 9, 931. [CrossRef]

52. Good Food Oxford. Newcastle Food Network and Blackburn with Darwen for Food Power Alliances Who Are Taking an Inclusive. Available online: https://www.sustainweb.org/foodpower/case_studies/ (accessed on 10 October 2019).

53. Nygreen, K. PAR: Toward a New Theory of Engaged Research for Social Change. Soc. Justice 2009, 36, 14-35.

54. The House of Lords Inquiry into Food, Poverty, Health and the Environment. 2019. Available online: https:/committees.parliament.uk/work/8/food-poverty-health-and-the-environment/publications/ written-evidence/ (accessed on 18 March 2020).

(C) 2020 by the author. Licensee MDPI, Basel, Switzerland. This article is an open access article distributed under the terms and conditions of the Creative Commons Attribution (CC BY) license (http://creativecommons.org/licenses/by/4.0/). 